\title{
AZ IMAGE MINT A VÁROSMARKETING ESZKÖZE
}

\author{
(Image as a tool of city marketing)
}

SZAKÁL GYULA

\section{Az image szerepe a városmarketing kutatásban}

Az 1910-es években útjára indult marketing tudománya sajátos és igen érdekes fejlödés- és fordulóponthoz érkezett, amikor napjainkban érdeklödése a tájak és települések felé fordul. Ez az új terület igen izgalmasnak bizonyul, mert amíg a gazdasági gyakorlatban különböző piaci részek különíthetők el, addig a városok, falvak és kisebb-nagyobb régiók esẹtében szinte mindenkor az egyes ember, vagy embercsoportok kerülnek a vizsgálódás fókuszába. A városvezetés és a vállalkozók településhez tapadó gazdasági érdekeihez képest egészen más igényeket fogalmaznak meg az iskolák, a kulturális és tudományos intézmények és a polgárok. A város- és területmarketing jellegzetessége még, hogy az "eladandó" objektum hosszú távon mindig a maga egészében fejti ki hatását. Egy-egy elemét ki lehet ugyan emelni és ủgyes reklámfogásokkal önálló életre lehet kelteni, de a települések és tájak esetében minden elem hat és ha valamelyik rossz hatásfokkal múködik, az egész nem dobható el. A térségi viszonyok elemzésével sok esetben ezért mondanak csödöt a hagyományosan jól bevált technikák.

A helyi politikusok és a szakemberek figyelmét igen gyakran elkerüli az a roppant fontos tény, hogy egy adott telepuilésen élés lehetősége nem azonos azzal, hogy érdemes-e ott élni. A települések, különösen a városok valós helyzete mellett kialakul azok pszichés megítélése is. Mindmáig nem fordítottak kellő figyelmet arra, hogy mindig létrejönnek alul- vagy felülértékelt területek és hogy a mentális megitélés milyen hatalmas mértékben serkentheti vagy gátolhatja a fejlödést. Gyỏr története iskolapéldája lehet ilyen helyzet kialakulásának. Az 1870-es években pár év leforgása alatt a leggazdagabb kereskedök száma 87-ról 17-re apadt a városban. A távolsági gabonakereskedelem lehanyatlásával valóságos katasztrófahangulat alakult $\mathrm{ki}$ a városban. A valós helyzet túldramatizálásának következményeként 67 igen gazdag polgár vitte el a pénz-, kapcsolati és tudástókéjét, holott a város gazdasági esélyei továbbra is kiválóak maradtak, amit nem sokkal később a gyáripar megtelepedése és sikere bizonyított.

Napjainkban a mentális megítélésre pedig legjobb példa, hogy az értelmiség számára vonzó, vagy netán taszító egy város. Ha ez az értelmiségi közvélemény sok esetben túlzó is, mindig valamilyen probléma meglétét jelzi. Az is elgondolkodtató, hogy a városok 
vezetésének többsége alig érzékeli ezt a problémát, holott a kvaterner erôforrásokért való küzdelem lesz a jövö egyik legfontosabb településfejlesztési gondja.

A városok és tegyük hozzá a régiók versenyében is egyre fontosabb szerepet kapnak az ún. „puha” tényezők. A környezet minősége, a helyi kulturális kínálat, a szabadidős lehetóségek, a helyekhez vagy eseményekhez köthető pszichés vonzás (Eger, Debrecen, vagy Pécs esetében) mind olyan tényezők, amelyek kvantitatív módszerekkel szinte hozzáférhetetlenek és a hagyományos szemlélet számára nem is igazán izgalmasak. Napjainkban mind a konkurencia (az egyes települések adottságainak az összevetése), mind pedig a hatékonyság-elemzések (a településeken belüli faktorokat vetik össze egymással, vagy a potenciális lehetöségekkel) egyre gyakrabban támaszkodnak olyan tényezökre, amelyeket nehéz, vagy lehetetlen számszerúsíteni.

Jól használhatónak bizonyultak a Multikritérium Értékelési Technikák (MCE), amelyek gyakran támaszkodnak a hagyományos költség-haszon elemzésekre. Ebben a módszerben pedig egyre fontosabb szerepet kapnak azok a szempontok, amelyeket igen nehéz kvantitatív módszerekkel vizsgálni. Ilyenek a hely jellegéböl adódó haszonköltségek. A festói útvonalak, az ingergazdag környezet, az áttekinthető tér; a közérthetỏ és látható vizuális információhordozók vonzó hatásúak, míg hiányuk szorongásos magatartást idéz elö. Az érzéki haszonköltségek, mint amilyenek a kellemetlen zaj és szag, a túlzsúfolt utcák, az elhanyagolt városkép, a piszkos tömegközlekedési eszközök összhatása megfoghatatlan és tárgyiasithatatlan rossz hangulatot idéz eló.

A pszichikai haszonköltségeket nemhogy számszerüsíteni, de még szavakba ơnteni is nehéz. A személyi biztonság érzése, a taszító feliratok és falfirkák, a város hangulata „levegője”, a polgárokra jellemzó mentalitás (befogadó-kirekesztö, segitőkész-ellenséges, inspiráló-visszafogó) hagyományos fogalmaink és eszközeink elótt rejtve maradnak, pedig ezek a tényezők mindenkit személyesen érintő problémák. A marketing filozófiában axiómának kell tekinteni, hogy a vásárló, így a várost és régiót kereső, vagy már használó emberek nem árucikket keresnek, hanem a problémáikra kívánnak megoldást találni. Az image problémafelismerö és döntésbefolyásoló szerepe akkor pótolhatatlan, amikor a vizsgált terület a hagyományos számszerũ vagy verbális eszközökkel kutatva rejtve marad előttünk.

\section{Mit rejt az image fogalma?}

Az image fogalma hosszú ideig csak a pszichológiában fordult elő. Azt a képzetet image-t - keresték, amely a hirdetések, a csomagolás nyomán az emberekben keletkezik, és jelentős mértékben meghatározza a vásárlással kapcsolatos döntéseket. A klasszikus reklám világában felhalmozott ismeretek csak nehezen tudtak maguknak új területeket meghódítani. A 60-as évektől tủnt fel ez a fogalom a városok vonatkozásában, és lényegében ezzel egyidőben kezdtek figyelmet forditani az intézmény-, személy-, foglalkozás-, és a nemzet-image problémájára. 
Fokozatosan vált csak nyilvánvalóvá, hogy környezetünket végtelenül gazdagon és sokféleképpen építjük be gondolkodásunkba és cselekedeteinkbe anélkül, hogy mindezt naponta tudatosítanánk. Sokkal többról van szó, mint a környezet gondolkodásunkat, érzelmeinket befolyásoló szerepéról. Az egyén sohasem a külső világ valós fizikai megjelenése alapján tájékozódik, él, mozog a térben, hanem mindig a benne élő szubjektiv kép alapján cselekszik.

A várost mint a körülöttünk létező objektív környezetet mindig csak pillanatában látjuk, észleljük, ebböl alkotunk magunknak egy képzetet, amelyet érzelmileg interpretálunk. Erre építve teremtjük meg a város image-ét, amikor a városképzetből kis számú, tipikusnak tartott elemet emelünk ki, sajátos egyediséggel ruházzuk fel, szinte újrateremtve magunk számára a települést.

Ezáltal szükebb és tágabb környezetünket vagy annak részeit mindig jelentéssel ruházzuk fel, s így módosul - nem ritkán teljesen átértelmeződik - a városrészhez, városhoz, tájhoz, régióhoz való viszonyunk. Az ember mindig megteremti a maga mentális környezetét, ahol mindent személyes jelentésében él meg. Ebböl következik, hogy az egyén fizikai, érzelmi valóságának részét képezi az a tér, amivel érzelmi kapcsolatban van.

\section{Az image-vizsgálat fajtái}

A környezeti image-eket leggyakrabban kiterjedésük alapján osztályozzák. Ennek alapján mikrotérségi (ház, lakás), mezotérségi (városrész, város) és nagytérségi (tájegység, régió) image-ek léteznek. Az emberi magatartảshoz való viszony alapján egyéni, csoport-, nemzet- vagy újabban kontinentális image is elképzelhetỏ. Gondoljunk csak az európaiság napjainkban oly gyakran használt fogalmára. A piaci viszonyokhoz a termék, az intézmény (gyár) és a gazdasági pozíció image-e köthetö.

A szép környezet tudati képének hatását már régen felismerték. A gyönyörủ táj lélekemelö szerepére az elsők között a költök és írók figyeltek fèl. A későbbiekben már a tudomány is felfigyelt a táj esztétikai karaktereire. A domborzat formái, a vízrajzi kép, a természetes növénytakaró és az emberi tevékenység nyomai nemcsak gazdasági tényezök, hanem az emberi környezet olyan elemei, amelyeknek jelentésük van és szimbolikus világunk részévé válnak.

Az ember sajátossága, hogy az öt körülvevö földrajzi tér elemeinek személyes jelentést tulajdonít. A megtapasztalható környezet ezáltal kitágul, hiszen a szimbolikus tér tapasztalhatósága határtalan. Ez azt is jelenti, hogy az egyén élettörténete a mindenkori környezetével kölcsönhatásban bontakozik ki és ezáltal saját testének határai is kitágulnak. Az individuum nem ott ér véget, ahol teste lehatárolja öt, hanem azt a környezetet is magáénak érzi, amelyre kivetíti önmagát. Ezáltal válik a mindennapi környezethasználat a falvak, városok, tájak és emberek azonosságérzetének igen fontos elemévé.

Az 1960-as évektöl kezdtek foglalkozni a táj szépségével, esztétikai értékének vizsgálatával, majd a hetvenes évektöl kísérletet tettek a müvészet által kifejezett földrajzi szépség 
tudományos megragadhatásának a problémájára. Közvetlen gyakorlati eredményeket hozott a regionális image-ek vizsgálata, amelyeknek legmarkánsabb alkalmazása a lakóhely-preferencia területén történt meg.

A legfeltúnöbb eredmények mégis a városi image területén születtek. A legizgalmasabb kérdés a magatartás és az image közötti kapcsolat feltárása volt. Kísérletet tettek a városi életet fenyegető természeti és társadalmi veszélyek tudati elemeinek a feltárására, szerepére a településen belüli migrációban.

Fontos szerepet kapott a városi image legátfogóbb elemeinek a meghatározása, ami nélkül tudatos várospolitika nem képzelhető el. Eszerint egy város image-e akkor jó, ha az ipar és a legkülönfélébb szolgáltatások a többi településsel szemben kiemelten előnyben részesítik. Különösen vonatkozik ez új ágazatok megtelepedésére, a bank-, biztosítási és az idegenforgalmi szférára. Ugyanígy, ha gyakran és rendszeresen ad otthont országos és nemzetközi kongresszusoknak, ha a tudomány, múvészet és a gazdaság kiemelkedő egyéniségei gyakran fordulnak meg a városban és szívesen telepednek le ott. Ha a városban született ipari termékek, müvészeti és tudományos teljesítmények állandóan jelen vannak az idegenek szélesebb körének tudatában. Végül, de nem utolsó sorban, ha a természetes és épitett környezet megállásra készteti azokat az idegeneket, akiknek ez egyébként nem állt szándékában.

Természetesen a táj és a települések nem bonthatók szét automatikusan. Kétségkívül igaz, hogy egy fôldrajzi tájon (pl. Kisalföld) vagy egy közigazgatási egységen (megye) belül a városok egymással szemben fogalmazzák meg karakterüket. Ugyanakkor a távolság növekedésével az idegenek szemében már egyesül a terület. Egy nagyobb térségből választanak ki egy-két tipikus elemet és teszik az image meghatározó bázisává. Így vált a két szélsőséges pólus, Budapest és a puszta (Hortobágy) a külföldiek szemében Magyarország meghatározó jellemzỏjévé.

\section{Az image kutatás eredményeinek alkalmazása}

A városmarketing kutatásának és gyakorlati alkalmazásának már számos koncepciója áll rendelkezésünkre. Az egyik leghasználhatóbbnak - különösen a kezdeti lépések megtételéhez - Meffert folyamat tervezési modellje bizonyult, amelyben a régi és kipróbált módszerek kiegészülnek eddig kevésbé ismert vagy új ötletekkel. Ez a négylépcsős információ-feldolgozó, elemző és végrehajtó rendszer kellően rugalmas ahhoz, hogy elöítéletektöl mentesen kezelje az eszményképeket, a célokat és az intézkedéseket. (Lásd: City-Management, City-Marketing, Stadtmarketing Heft 129, Lehrstuhl Wirtschaftsgeographie und Regionplanung, Universität Bayreuth, Bayreuth 1993).

Meffert modellje sem mentes azonban attól a hibától, hogy túl egyszerü és objektív városképben gondolkodik. Ez a redukcionizmus ugyan könnyen kezelhetővé teszi a rengeteg feldolgozandó információt, de az emberi magatartás érzékelésének és hatásának a körét végletesen leszúkíti. Ennél a kérdéskörnél válik az image-kutatás szinte pótolhatatlanná. 
Fel kell ismerni, hogy az emberi viselkedés számára nincs objektív város. Mindig szubjektív észlelésünk és véleményünk alapján cselekszünk. A helyzetelemzés és a pozícióbiztosítás fázisában (Meffert kiindulópontja) a városkép észlelése, a térhasználat milyensége, az ellátási tényezők (közigazgatási, kereskedelmi, egészségügyi, oktatási, kulturális szolgáltatások) egyéni értékelése mind-mind olyan elemek, amelyek hozzásegítenek saját belsõ „városunk" felépítéséhez (image). A hagyományos marketingszemlélet számára nehezen érzékelhetỏ az a tény, hogy a várost (és a régiót) sokkal inkább a szubjektív tapasztalatok és viselkedési minták összjátéka avatja áruvá, mintsem a hagyományos kereskedelmi termékeket. Az ingerforrások száma és bonyolultsága annyira növekszik, amit már lehetetlen csak racionális módon kezelni. Arról nem is szólva, hogy míg egy elönytelen vásárlás után a mosópor, kávé, fogkrém stb. esetében nem jelent gondot a termékfajta megváltoztatása, addig a települések esetében az érzelmi kötődésen túl az anyagi lehetőségek is gátat szabnak változtatási szándékunknak. Ezért a településmarketing vizsgálatok során szubjektív véleményekkel, a kognitív disszonanciák megjelenésével sokkal szélesebb körben találkozunk mint az iparcikkek esetében.

Az erős és gyenge pontok meghatározása, a lehetőségek és a korlátok elemzése, előrejelzése sokkal inkább a szubjektiv dimenzió feltárásán alapul, mint bármilyen más árufajta esetében. A „városleltár" elkészítésénél (hogyan lehet a jelenlegi helyzetet leírni, milyen erỏs és gyenge pontok figyelhetők meg, hogyan értékelhetö a konkurencia, milyen átfogó célokat lehet kijelölni) ma már nem elégséges az ún. kemény tényekre építeni. A jövőbeni döntés-elókészítések sokkal inkább figyelembe veszik majd a polgárok szubjektív véleményét és viselkedését, mint gondolnånk.

A helyzetelemzés után szükséges egy városfilozófia kidolgozása. (Meffert városmarketing felfogásának második etapja.) Az eszményképek és víziók kidolgozása új és igen fontos elem a jövó marketingjének eszköz- és célrendszerében. Ez a szemlélet nem azonos a naturális növekedési politikával (lakások építése, eladása, iskolai, egészségügyi hálózatbővítés), mert a városfilozófia sokkal inkább a polgárok gondolkodására, magatartására, mentalitására épít, egy új eszménykép kialakítását célozza meg és nem a fizikai paraméterek megváltoztatására koncentrál. A külföldi vizsgálatok (pl. Naisbitt) szerint 2000-ben az emberek mindössze 10\%-a keresi csak a munka utáni passziv pihenést. A többség (50-60\%-a) számára a szabadidó és annak térbeli keretei jelentősen felértékelödnek. Az „életvállalkozó” ember számára a környezeti élmények és a közösség, a városok hangulata sokkal fontosabb lesz, mint jelenleg és egyéni megitélést fog kapni.

Azok a városok boldogulnak majd, amelyek képesek lesznek eszményképet megfogalmazni. Ezeknek a vízióknak a létrehozása komoly teljesítmény, amit a polgárok gondolkodási és viselkedésmodelljei hordoznak ugyan, de kibontásukért a mindenkori vezetés a felelős. Ez a felelösség ma óriási, hiszen nálunk a civil társadalom ereje még egy ideig gyenge lesz ahhoz, hogy ilyen irányú akaratát érvényesítse. A folyamat első lépése a város belsố vonzóerejének a növelése, a különbözö igénycsoportok megelégedettségének javítása és végül a polgárok identitásának kialakítása. Ennek valódi hátterét a helyi tórsadalom gazdasági eredményei, önszervezödö képessége, kollektiv élményei, valamint sikerei 
(sport, kulturális, gazdasági stb.) biztosítják. A külföldi tapasztalatok azonban arra intenek bennünket, hogy a tudatos várospolitika sehol sem nélkülözhető.

A mefferti programban külön helyet foglal el a kommunikációs politika (stratégiai tervezés-marketing-mix), amiben komoly szerepet kaphat a város image kutatása és az eredmények gyakorlati alkalmazása. A nagyobb települések tudatosan, vagy csak részben átgondoltan eddig is folytattak reklám- és PR-tevékenységet. Mivel a város-image feltárása, tervezése és állandó kontrollja az emberi magatartás legrejtettebb dimenzióit tárja fel, így a kommunikációs politika hatékonyságát az egyéb módszerekkel hozzáférhetetlen mikroszinten (egyének, kiscsoportok, városrészek) is képes megnövelni. Feltárhatók általa a nem tervezett és negatív image elemek és a város fehér foltjai is.

\section{Példa egy töredezett város image-re - Györ}

A szemléletében és módszereiben (tartalomelemzés) korszerünek tekinthetö és éppen meginduló mentalitáskutatás Györ esetében igen karakteres és a polgári társadalom életvilágából tóplálkozó szerves város- és polgạ́r image-t tárt fel az 1930-as évekig. A város az élénk forgalomban, a folyókon úszó teherhajókban, a mozdonyok zajában és a parton sorakozó raktárak soraiban jelenik meg. A település látványa a benne zajló élet ízig-vérig a polgári lét világát jelenti. A hangulatos vendéglök, kávéházak, sétányok éppúgy részei ennek az életmódnak, mint a csónakázás, a vízi kirándulások vagy a közeli dombvidék nyújtotta pihenési lehetőségek. Mondani sem kell, hogy az 1860-as években járunk, amikor Györ a kereskedelemben véli felfedezni önmagát.

A századfordulóhoz közeledve a kereskedelmi szerep lecsengésével megváltozik a város énképe. A település múltbéli fontossága, arculata, tekintélye és korabeli gazdasági élete válik Györ lényegévé. Az 1890-es évektöl datálható eröteljes iparosítás a harmincas évekre átformálja a kereskedôvárosi hangulatot és megjelenik a gyár élménye. Az igazi image-ét már az iparvágányok, a gyárépületek és a raktárak adják, amire büszke lehet minden polgár. Az általános kép hátterébỏl kibontható az emberek perspektivikus szemlélete, önbizalma és öntudata, amelyek mögött a régröl ismert szorgalom és szaktudás áll. Ezek a tulajdonságok individualizmussal, a szélsöségektöl való tartózkodással és a szülóvároshoz való ragaszkodóssal ötvözödtek.

A kiragadott példákból látható, hogy Győr esetében egy változó, de mindenkor karakteres és kerek egész város- és polgár-image tapintható ki. Feltünö, hogy milyen eröteljes igény fogalmazódott meg az önreflexióra, amit a helyi társadalmi nyilvánosság (sajtó, kiadványok) állandóan a felszínen tartott.

Egy emberöltővel később, napjainkban már csak egy elemeiben élő, töredezett image bontható ki. A régi stigmák már alig vannak jelen a györi polgárok gondolkodásában. Így a kereskedöváros, a Nyugat kapuja, söt még a vizek városa jelzö is csak nagyon szerényen él a köztudatban. Az elmúlt évtizedek kötelezően propagált iparvárosi szlogenjétöl kifejezetten szabadulni szeretne. A töredezettség és az arctalanság nemcsak a múlttal kap- 
csolatban jelent meg, hanem a jelen állapotra is vonatkozik. A városhoz kapcsolható olyan ritka, szép különlegesség, mint a múemlékekben gazdag belváros, alig kapott említést. A legközismertebb image-hordozó elemek, mint a városban elóállított ipari termékek és a szellemi teljesítmények is ilyen sorsra jutottak. A legtöbben a lakóhellyel és a szülöhellyel azonosították Győrt minden különösebb jellegzetesség nélkül.

Sikerült ugyan előcsalogatni néhány mélyen megbújó rejtett image-elemet, amelyek igen töredezetten léteznek a győriek tudatában, de akiknek a teljesen nyilvánvaló fizikai valóság, mint a müemlék jelleg, a külvárosi gyárak és a folyók jelentik a város érzékelését. A töredezettség mellett a véleményekben érzékelhető volt még valamilyen nehezen megragadható kereskedóvárosi hangulat és nyugati szellem. A szétforgácsolt múltkép és a bizonytalanság után az azonosságérzés hiánya dominált. Talán ennek köszönhetö, hogy a vizsgálatban megkérdezett gyóriek több mint felének más városok jobban tetszettek.

A múlthoz képest figyelemre méltóan változott a győri polgárok karakterének a megítélése. A munkaszeretet és a takarékosság erényei régi környezetükből kiszakítva tovább éltek az elmúlt évtizedekben is. Mellette azonban felbukkant a kispolgári jelleg, a befelé fordulás, a lelketlenség és a kulturális igénytelenség érzete.

A szétforgácsoltság, a bizonytalanság és az identitás hiánya mellett új image elemként az ellentmondás bukkant fel. A nagyvárosi társadalmi milió mellett mikroszerkezetében Győr kisvárosként müködik. A mindennapi reakciók, az értékvilág és a perspektívák megítélése tipikus kistelepülési hátteret sejtet. Erre utalnak az egymástól függetlenül végzett felmérések, amelyek Győrt nem tekintik életvidámnak. A munkalehetőségek kínálata mellett a meglévó nagyvárosi funkciók sem váltak érzékelhetóvé a polgárok tudatában. Az életvidámság és a mentális vonzás ezért kapott igen rossz megítélést. Ezzel kapcsolatban nem lenne haszontalan felderíteni, hogy a fizikai és humán környezetünkről alkotott kép miképpen változik az egymást követő nemzedékekben.

Ez a esettanulmány figyelmeztet arra, hogy a városmarketing kutatása és gyakorlata során mennyire fontos az emberi magatartảs, a fejünkben lévő fizikai és mentális világ. Egy valóban bölcs és hatékony településpolitikát nem lehet a polgárok nélkül, vagy netán ellenükre megvalósítani sem a települések, sem pedig a régiók vonatkozásában.

\section{Irodalom}

Cséfalvay Z. (1990) Térképek a fejünkben. Akadémiai Kiadó, Budapest.

Cséfalvay Z .- Wolfgang, F (1990) Cigányzene és lakáshiány-sztereotípiák és a valóság ellentéte a Budapest képben. Földrajzi Értesitó, 1-4. füzet, 207-220. o.

Lynch, K. (1981) A városkép észlelésének a struktúrája. In: Vidor Ferenc (szerk.): Urbanisztika. Gondolat, Budapest.

Kozma G. (1993) Az image-építés helyzete Groningenben és Debrecenben. Közlemények a KLTE Földrajzi Intézetéböl, Nr. 185. 1993.

Kozma G. (1995) A debreceni önkormányzat elsó lépései a városmarketing területén. Comitatus, 5. 15-21. o

Szakál Gy. (1993) Ember és kơrnyezet viszonya a györi polgárok tudatában, Mühely, 1. 43-49. o.

Szakál Gy. (1993) Tájak és települések képe az ember tudatába. Comitatus, 5. 39-43. o.

Szakál Gy. (1994) Telepulések, tajak image-e. Cash-Flow, 1. 66. 0.

Tóth G. (1994) Milyen képet vágjunk. Marketing, 4. 292-294. o. 
Tér és Társadalom 9. évf. 1995/1-2. 32. p.

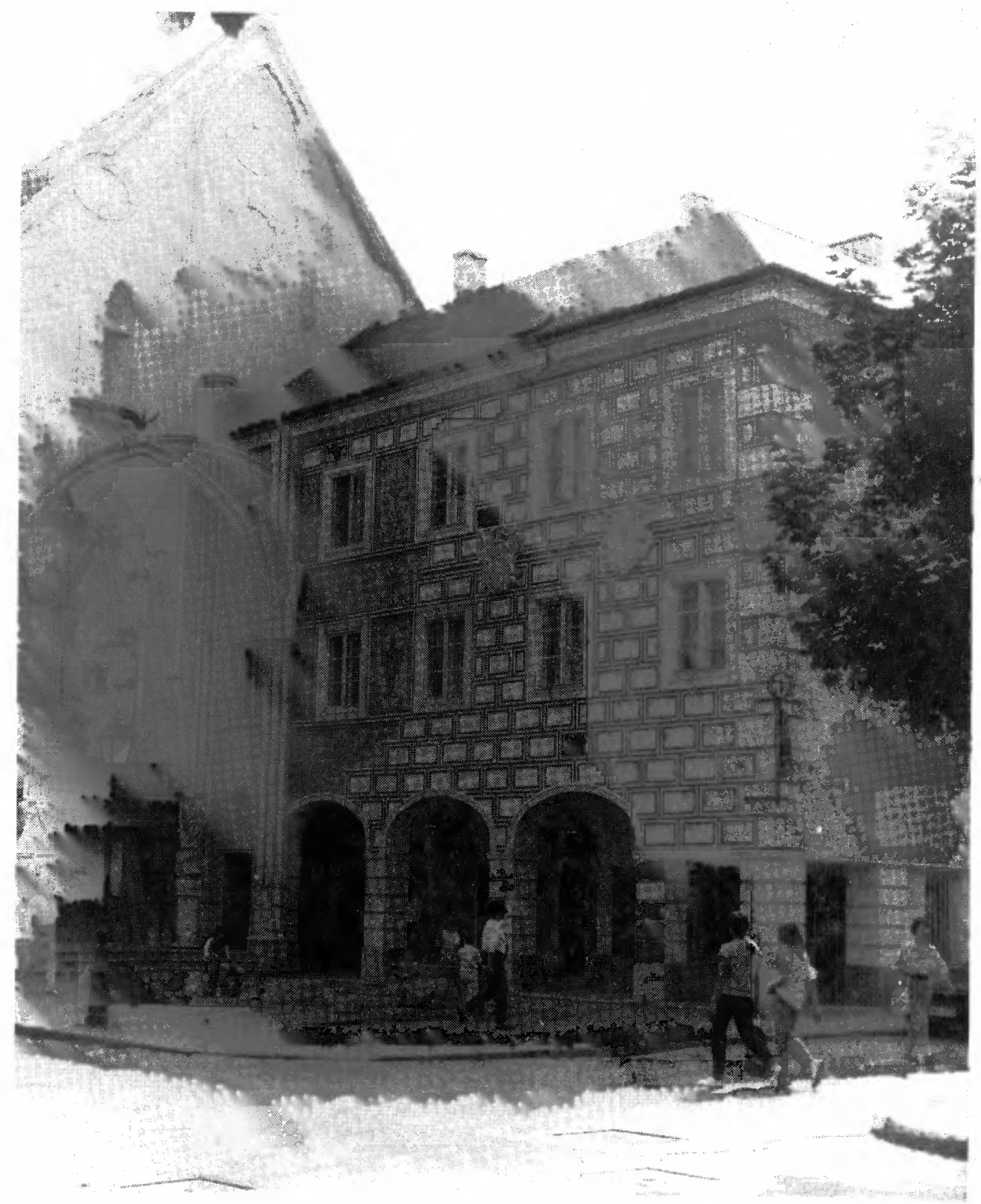

A történelmi Székesfehérvár - Fö utca

(MTI FOTÓ - Kabáczy Szilárd) 